\title{
Population Dynamics of the Whitefly, Bemisia Tabaci (Gennadius) (Homoptera: Aleyrodidae) on Common Bean, Phaseolus Vulgaris in Relation to Cultivar, Temperature and Humidity
}

\author{
Amal I. Safe ${ }^{1}$, EL-Saied A. Naiem ${ }^{1}$, Horia. A. Abdel-Whab ${ }^{2}$ and Kamal M. El-Gendy ${ }^{2}$
}

\begin{abstract}
The objectives of this study were to find the correlation between population dynamics of the whitefly, Bemisia tabaci, Phaseolus vulgaris cultivars, temperature and humidity during the summer and winter growing seasons of 2013 and 2014. The three $P$. vulgaris cultivars screened were Copy, Polesta and Manga. In 2013 and 2014 cropping seasons, the population densities of $B$. tabaci gradually increased from the $3^{\text {rd }}$ week of March until the $4^{\text {th }}$ week of April. For, the population density increased and reached a peak from the $1^{\text {st }}$ week of May, and then the population density decreased gradually from the $4^{\text {th }}$ week of May until the $3^{\text {rd }}$ week of June in 2013 and $1^{\text {st }}$ of June in 2014. Densities of this pest typically increased as the growing season progressed and reached a peak in November and started to decrease from $1^{\text {st }}$ of December until the end of them. In 2013 and 2014 cropping seasons, the population densities gradually increased from the $2^{\text {nd }}$ week of October until the $4^{\text {th }}$ week of October. Furthermore, the population density reached a peak from the $1^{\text {st }}$ week of November, and then decreased gradually from the $4^{\text {th }}$ week of November until the $4^{\text {th }}$ week of December in 2013 and 2014. In 2013 summer cropping season, the cultivars Copy and Polesta were the most infested varieties. A similar trend was observed during 2014 summer growing season. In 2013 winter cropping season, the cultivars Copy and Manga were more susceptible to white fly infestation than Polesta cultivar. A similar picture was obtained during the winter cropping season of 2014. The most infested varieties were Copy and Manga respectively. Whereas Polesta variety was the least infested. $B$. tabaci population density was positively affected by temperature in 2013 and 2014 summer growing seasons, where the correlation coefficient were 0.64 and 0.6 , respectively. In contrast, in 2013 and 2014 winter cropping season the relationship between $B$. tabaci population and temperature was insignificant and/or significant and negative with a correlation coefficient of $\mathbf{- 0 . 1 4}$ and $\mathbf{- 0 . 6 1}$ respectively. The results revealed that the relative humidity showed nonsignificant positive association with $B$, tabaci abundance in 2013 summer growing season with correlation coefficient of 0.08 . On the other hand, $B$. tabaci density showed nonsignificant negative association with relative humidity in 2014summer season and 2013 winter seasons and significant negative association in 2014 winter season with correlation coefficients of $0.18,0.73$ and 0.32 respectively.
\end{abstract}

\footnotetext{
${ }^{1}$ Department of Zoology, Faculty of Science, Tanta University, Tanta, Egypt

${ }^{2}$ Department of Vegetables Pests, Institute of Plant Protection,

Agricultural Research Center (ARC), Dokki, Giza, Egypt

Received May 20, 2018, Accepted June 27, 2018
}

Keywords: Bemisia tabaci; Population Dynamics; Whether Conditions; Common Bean.

\section{INTRODUCTION}

The common bean, Phaseolus vulgaris L. (Fabaceae), is an annual leguminous plant. It forms an important vegetable and pulse cash crop worldwide, including Egypt. It has high protein content and is a good source of energy and provides folic acid, dietary fiber and complex carbohydrates (Filella and Penuelas, 1994). Common beans contribute up to $57 \%$ of recommended dietary protein and $23 \%$ of energy to the nutrition of African people (Shellie and Hosfield, 1991). In 2014 , total world production of dry beans was 25.8 million tons, harvested from over 37 million hectares. World production of green beans in 2014 was 21.7 million ton, harvested from 15.3 million hectares. Meanwhile, the Egyptian production was 253110 tons harvested from 25069 hectares (FAO, 2014). In recent years, crop production trend has not kept pace with the annual growth rate (estimated above 2 percent) in population in some countries due to number of biotic, abiotic and socio -economic constraints (Katungi et al., 2009). Hassan et al. (2016) found that the two inspected and identified insect species on garden peas foliage were Liriomyza trifolii and Bemisia tabaci. The white fly, Bemisia tabaci (Gennadius) (Homoptera: Aleyrodidae), is highly polyphagous and has been recorded on a very wide range of cultivated and wild plants. In Egypt, B. tabaci is among the pests that inflict a heavy toll on $P$. vulgaris production (Amaar et al., 2014). B. tabaci sucks the sap from plants causing wilting, yellowing, shedding leaves and reduces growth rates and productivity if infestations are severe (Oliveira et al., 2001). Apart from direct damage, they transmit plant pathogenic viruses and acts as an efficient vector of numerous Gemini viruses (Basu, 1995). In addition, they produce honeydew which supports sooty mould growth, which reduces photosynthesis and decreases plant vigor (Oliveira et al., 2001). The environmental conditions such as temperature and relative humidity are considered limiting factors to the growth and fertility of B. tabaci (Amaar et al., 2014 and Gamila Sh. Selem et 
al. 2016). Varieties of crops differ in their pest resistance. An insect resistant plant offer ideal prevention against pest infestation and damage. The use of resistant varieties is a major pest management practice and is one of the most economical and effective methods of control (Dhaliwal and Arora, 2003). Knowledge on varietal preference of the whitefly can play a significant role in the successful common bean production and management. The specific objectives of this study were to determine the population dynamics of the whitefly, B. tabaci on three P. vulgaris cultivars and to correlate the effect of weather factors on the population dynamics this pest. The study was also undertaken to evaluate the common bean varieties for identifying the possible resistant varieties against infestation by B. tabaci.

\section{MATERIALS AND METHODS}

\section{Study area}

All experiments were conducted at the experimental plot of Etay EL-Baroud Agriculture Research Station, EL-Beheira Governorate, Egypt. The experiment area was 0.21 hectar. In the area, seeds of crops, Polesta and Manga common bean cultivars were sown in separate beds. The experiments were conducted in both summer and winter common bean cropping seasons of 2013 and were repeated in the same seasons of the year 2014 to ascertain the population dynamics of B. tabaci. In 2013, the summer cropping season began on the $3^{\text {rd }}$ of March until the $3^{\text {rd }}$ of June and in 2014 the cropping season began on the $3^{\text {rd }}$ March until the $1^{\text {st }}$ of June. The winter cropping seasons commenced from $15^{\text {th }}$ of September to $4^{\text {th }}$ of December in 2013 and from $22^{\text {nd }}$ of September to $4^{\text {th }}$ of December in 2014. Seeds were sown on one side of the row at $20 \mathrm{~cm}$ hill spacing using two seeds per hill. All common bean cultivars were maintained using standard agronomic practices recommended for raising the crops (seedbed preparation, irrigation and fertilization) and the plants were not sprayed with pesticides.

\section{Bemisia tabaci sampling protocol}

The study of the population dynamics of the whitefly was laid out in a Completely Randomized Block Design (CRBD). The experiment area was 350 $\mathrm{m}^{2}$ divided into four replicates (plots), the replicate area was $84 \mathrm{~m}^{2}$. Each replicate consists of three plots. The plot size was 10 rows with four meters long and $70 \mathrm{~cm}$ apart with total area $28 \mathrm{~m}^{2}$. Seeds were hand sown on one side of the row at $20 \mathrm{~cm}$ hill spacing with two seed per hill.

Monitoring of B. tabaci population was conducted throughout the summer and winter growing seasons until the end of the fruiting stage in the three common bean cultivar plots. Sampling was carried out at weekly interval early in the morning before the whitefly adults tend to be more active (Gameel et al., 1973). Population densities of whitefly were assessed by leaf random sampling. For sampling, 30 leaves representing top, middle and bottom canopy were picked from each of the three common bean varsities were randomly selected per planting plot. Thus, in all 120 leaves/replicat were observed at one time for each variety. Leaf samples were kept in separate paper bags properly labeled with plot number. The leaves were then brought to the laboratory on the same day where the larvae and pupae of whitefly were counted under a stereoscopic-microscope. The density of B. tabaci in each plot in a given week was calculated.

\section{Collection of meteorological data}

Data on temperature and relative humidity in each week were obtained from the Metrological Records of General Center Laboratory for Agriculture Climate, Agriculture Research Center, Dokki, Giza (Preventative El-Behaira Governorate). The weekly average temperature and relative humidity were calculated. The simple linear regression between the whitefly density and temperature and/or relative humidity were used to determine the effects of the two whether factors on the weekly mean numbers of this pest during both growing seasons.

\section{Statistical analysis:}

Effects of cultivars, climatic factors on the population dynamics of Bemisia tabaci, simple correlation and partial regression were carried out using a computer software package, "Costat" a product of Cohort software In C., Barkeley, California, U.S.A.

\section{RERSULTS}

Population dynamics of Bemisia tabaci on Phaseolus vulgaris cultivars during the summer cropping season

The weekly average densities of $B$. tabaci monitored over the summer of 2013 and 2014 on common bean cultivars are shown in Table 1 . There was a significant difference $\left(\mathrm{F}=9.37^{* *} ; \mathrm{df}=66 ; \mathrm{P}=0.031\right)$ in the average population density of the whitefly larvae among all cultivars during the summer cropping seasons.

Populations of B. tabaci infested the three common bean cultivars during crop seasons of 2013 and 2014 were initially detected in early March. Densities of this pest typically increased as the growing season progressed and reached a peak in the month of May and started to decrease from June until the end of the seasons. In 2013 and 2014 cropping seasons, the population densities of $B$. tabaci gradually increased from the $3^{\text {rd }}$ week of March until the $4^{\text {th }}$ week of April. Thereafter, the population density increased and 
reached a peak from the $1^{\text {st }}$ week of May, and then decreased gradually from the $4^{\text {th }}$ week of May until the $3^{\text {rd }}$ week of June in 2013 and $1^{\text {st }}$ of June in 2014.

In 2013 cropping season, the population density of B. tabaci on crop cultivar started to increase from 31.1 larva per week/30 leaves in the $3^{\text {rd }}$ week of March to 95.3 larva per week $/ 30$ leaves in the $4^{\text {th }}$ week of April. It attained its peaks in the $1^{\text {st }}, 2^{\text {nd }}$ and $3^{\text {rd }}$ weeks of May (115.5, 133.8 and 135.8 larva/30 leaves), respectively. Afterwards, the populations started to decline from the $4^{\text {th }}$ week of May (83.5 larva per week/30 leaves) until the $3^{\text {rd }}$ week of June (59.8 larva per week/30 leaves). In 2014 , the population density was generally less than the 2013 cropping season. The population density of $B$. tabaci fluctuated between 28.0 larva per week / 30 leaves in the $3^{\text {rd }}$ week of March and 62.0 larva per week/30 leaves in the $4^{\text {th }}$ week of April. Subsequently, from the $1^{\text {st }}$ week of May through the $3^{\text {rd }}$ week, the population density fluctuated between 69.5 larva per week/30 leaves and 78.0 larva per week/30 leaves, then decreased in the $4^{\text {th }}$ week of May (58.5 larva per week/30 leaves) and increased again in the $1^{\text {st }}$ week of June (62.3 larva per week/30 leaves).

In 2013 cropping season, the population density of B. tabaci on Polesta cultivar started to increase from 26.25 larva per week/30 leaves on the $3^{\text {rd }}$ week of March to 56.75 larva per week/30 leaves on the $4^{\text {th }}$ week of April. It was significant increased during the first three weeks of May reached peaks on the $1^{\text {st }}, 2^{\text {nd }}$ and $3^{\text {rd }}$ weeks of May (127.25, 156 and 160.75 larva per week/30 leaves), respectively. Afterwards, the populations significant decreased on the $4^{\text {th }}$ week of May (83.5 larva per week/30 leaves), but it increased once again on the $1^{\text {st }}, 2^{\text {nd }}$ and $3^{\text {rd }}$ weeks of June (84.00, 97.00 and 88.00 larva per week/30 leaves). In 2014, the population density was generally lower than that of 2013 cropping season. The population density of $B$. tabaci fluctuated between 21.75 larva per week/30 leaves on the $4^{\text {th }}$ week of March and 49.50 larva per week/30 leaves on the $4^{\text {th }}$ week of April. Subsequently, the population density reached a peak on the $1^{\text {st }}$ week of May (63.50 larva per week/30 leaves) and decreased form 54.25 larva per week/30 leaves on the $2^{\text {nd }}$ week of May to 43.50 larva per week/30 leaves, on the $1^{\text {st }}$ week of June.

In 2013 cropping season, the population density of B. tabaci on Manga cultivar started to increase from 26.75 larva per week/30 leaves on the $3^{\text {rd }}$ week of March to 99.50 larva per week/30 leaves on the $1^{\text {st }}$ week of May. It attains its peaks on the $2^{\text {nd }}, 3^{\text {rd }}$ and $4^{\text {th }}$ weeks of May (128.25, 141.25 and 143.75 larva per week/30 leaves), respectively. Afterwards, the populations sharply declined from the $1^{\text {st }}$ week of June (52.25 larva per week/30 leaves) until the $3^{\text {rd }}$ week of June $(74.50$ larva per week/30 leaves). In 2014, the population density was generally lower than that of 2013 cropping season. The population density fluctuated between 23.75 larva per week/30 leaves on the $4^{\text {th }}$ week of March and 58.50 larva per week/30 leaves on the $4^{\text {th }}$ week of April. Subsequently, from the $1^{\text {st }}$ week of May through the $3^{\text {rd }}$ week, the population density fluctuated between76.75 larva per week / 30 leaves and 72.00 larva per week/30 leaves, then decreased on the $4^{\text {th }}$ week of May (55.25 larva per week/30 leaves) and decreased again on the $1^{\text {st }}$ week of June (54.75 larva per week/30 leaves).

\section{Population dynamics of Bemisia tabaci on Phaseolus vulgaris cultivars during the winter cropping season}

The weekly average densities of $B$. tabaci monitored on common bean-cultivars during the winter cropping seasons of 2013 and 2014 are shown in (Table 2). There was a significant difference $\left(\mathrm{F}=8.63^{* *} ; \mathrm{df}=60 ; \mathrm{P}=\right.$ 0.047 ) in the average population density of the whitefly larvae among all cultivars in the winter cropping seasons.

Populations of B. tabaci infested the three common bean cultivars during winter cropping seasons of 2013 and 2014 were initially detected early in October. Densities of this pest typically increased as the growing season progressed and reached a peak in November and started to decrease from December until the end of the seasons. In 2013 and 2014 cropping seasons, the population densities gradually increased from the $2^{\text {nd }}$ week of October until the $4^{\text {th }}$ week of October. Thereafter, the population density reached a peak from the $1^{\text {st }}$ week of November, and then decreased gradually from the $4^{\text {th }}$ week of November until the $4^{\text {th }}$ week of December in 2013 and 2014.

In 2013 cropping season, the population density of B. tabaci on Copy cultivar started to increase from 24.25 larva per week/30 leaves on the 2 nd week of October to 45.75 larva per week/30 leaves on the $4^{\text {th }}$ week of October. It attains its peaks on the $1^{\text {st }}, 2^{\text {nd }}$ and $3^{\text {rd }}$ weeks of November $(43.00,48.00$ and 52.75 larva per week/30 leaves), respectively. Afterwards, the populations started to decline from the $4^{\text {th }}$ week of November (27.75 larva per week/30 leaves) until the $4^{\text {th }}$ week of December (15.00 larva per week/30 leaves). In 2014 , the population density was generally lower than that of 2013. The population density fluctuated between 22.00 larva per week/30 leaves on the $2^{\text {nd }}$ week of October and 37.75 larva per week / 30 leaves on the $1^{\text {st }}$ week of November. Subsequently, from the $2^{\text {nd }}$ week of November through the $4^{\text {th }}$ week of the same month, the population density fluctuated between 43.50 larva per week/30 leaves and 52.50 larva per week/30 leaves, 
then decreased in the $1^{\text {st }}$ week of December (38.25 larva per week/30 leaves) until the $4^{\text {th }}$ week of December (20.75 larva per week/30 leaves).

In 2013 , the population density of $B$. tabaci on Polesta cultivar started to increase from 17.79 larvae per week / 30 leaves on the $2^{\text {nd }}$ week of October to 20.48 larva per week/30 leaves on the $4^{\text {th }}$ week of October. It was increased during the four weeks of May where its peaks in the $1^{\text {st }}, 2^{\text {nd }}, 3^{\text {rd }}$ and $4^{\text {th }}$ weeks of November (28.72, 35.46, 29.97 larvae per week/30 leaves), respectively. Afterwards, the populations decreased on the $1^{\text {st }}$ week of December (21.48 larva per week/30 leaves) until the $2^{\text {nd }}, 3^{\text {rd }}$ and $4^{\text {th }}$ weeks of December (13.24, 14.73 and 11.74 larvae per week/30 leaves). In 2014, the population density fluctuated between 13.25 larvae per week/30 leaves on the $2^{\text {nd }}$ week of October and 15.50 larva per week/30 leaves on the $1^{\text {st }}$ week of November. Subsequently, the population density reached a peak on the $2^{\text {nd }}$ week of November (28 larva per week/30 leaves) and decreased from 20.25 larvae per week/30 leaves on the $3^{\text {rd }}$ week of November to 18.75 larvae per week/30 leaves, on the $3^{\text {rd }}$ week of December.

In 2013, the population density on Manga cultivar started to increase from 14.79 larva per week/30 leaves on the $2^{\text {nd }}$ week of October to 23.08 larvae per week/30 leaves on the $4^{\text {th }}$ week of October. It attained its peaks on the $1^{\text {st }}, 2^{\text {nd }}$ and $3^{\text {rd }}$ weeks of November $(33.37,42.65$ and 48.92 larva per week/30 leaves) respectively. Afterwards, the populations decline from the $4^{\text {th }}$ week of November (31.86 larvae per week/30 leaves), until the $4^{\text {th }}$ week of December (12.79 larvae per week/30 leaves). In 2014, the population density was generally less than that of 2013. The population density fluctuated between 13.00 larva per week/30 leaves on the $3^{\text {rd }}$ week of October and 18.25 larva per week/30 leaves on the $1^{\text {st }}$ week of November. Subsequently, the $2^{\text {nd }}$ week of November showed the highest numbers of $B$. tabaci larva per week/30 leaves (33.75), then the population density decreased from 29.25 larva per week/30 leaves) on the $3^{\text {rd }}$ week of November to 22.75 larvae per week/30 leaves on the $3^{\text {rd }}$ week of December.

\section{Varietal screening of common bean Phaseolus} vulgaris cultivars against Bemisia tabaci

The average numbers of $B$. tabaci infesting the three common bean cultivars during the summer and winter cropping seasons of 2013 and 2014 are presented in (Table 3). The number of white flies infesting the three cultivars was statistically significant during 2013 and 2014 summer and winter cropping seasons. In 2013 summer cropping season, the cultivars Copy and Polesta were the most susceptible varieties with an average number of 84.13 and 82.19 larva/30 leaves, respectively. The cultivar Manga was less susceptible (76.63 larva /30 leaves). A similar trend was observed during 2014 summer growing season.

In 2013 winter cropping season, the cultivars Copy and Manga were more susceptible to white fly infestation than Polesta cultivar with average densities of 31.25, 26.14 and 22.95 larvae/30 leaves respectively. The similar trend was observed during the winter cropping season of 2014. The most susceptible varieties were Copy and Manga (34.39 and 23.36 larva/30 leaves), respectively. Whereas, Polesta variety was the least susceptible (10.11 larva/30 leaves).

\section{The relationship between temperature and relative humidity and Bemisia tabaci population density infesting}

As shown (Fig. $1 \& 2$ ), B. tabaci population density was positively affected by temperature in 2013 and 2014 summer growing seasons where the correlation coefficient were 0.64 and 0.6 , respectively. The significance of this relationship was shown in liner regression slope (4.51 and 3.24 respectively). These slope values indicated the strong relationship between $B$. tabaci density and average temperature in the summer season. Also, the data (Fig. 1 \& 2) clearly indicated that $B$. tabaci start infestation when the temperature average was above $15^{\circ} \mathrm{C}$, The population density reached a peak when the temperature average ranged between 20 and :30 ${ }^{\circ} \mathrm{C}$. Thereafter, the population density decreased when the temperature exceed $30^{\circ} \mathrm{C}$. In contrast, the relationship between $B$. tabaci and temperature in 2013 and 2014 winter cropping season was negative and insignificant with correlation coefficient of -0.14 and -0.16 , respectively (Fig. 3 \& 4). This associated was insignificant in 2013 with liner regression slope 0.63 , but it was significant in 2014 with liner regression slope 2.45 .

Data presented in Figs. from 5-8 revealed that the relative humidity showed non-significant positive association with B. tabaci abundance in 2013 summer growing season with correlation coefficient of 0.08 . On the other hand, B. tabaci density showed insignificant negative association with relative humidity in 2014 summer season and 2013 winter seasons and significant negative association in 2014 winter season with correlation coefficients of $0.18,0.73$ and 0.32 , respectively. These associations were not sharp in most cases where the liner regression slopes were $0.72,0.65$ and 0.57 in 2013, 2014 summer season and 2014 winter season except in 2013 winter season where the slope was very sharp (2.95). Generally, the data indicate that the white fly density of reached a peak when the relative humidity was less than $65 \%$. 
Table 1.Population dynamics of Bemisia tabaci on Phaseolus vulgaris cultivars during the summer cropping seasons of 2013 and 2014 summer plantation in El-Bihera Governorate

\begin{tabular}{|c|c|c|c|c|c|c|}
\hline \multirow[t]{2}{*}{ Month } & \multirow{2}{*}{ Week } & \multirow{2}{*}{$\begin{array}{c}\text { Average } \\
\text { temperature }\left({ }^{\circ} \mathrm{C}\right)\end{array}$} & \multirow{2}{*}{$\begin{array}{c}\% \\
\text { Relative } \\
\text { Humidity }\end{array}$} & \multicolumn{3}{|c|}{ Population densities of $\mathrm{B}$. tabaci on varieties of common } \\
\hline & & & & Copy & Polesta & Manga \\
\hline \multicolumn{7}{|l|}{2013} \\
\hline March & $3^{\text {rd }}$ & 21.4 & 59.39 & $31.75^{\mathrm{i}} \pm 0.55$ & $26.25^{\mathrm{k}} \pm 0.43$ & $26.75^{\mathrm{j}} \pm 0.47$ \\
\hline March & $4^{\text {th }}$ & 15.7 & 66.42 & $46.50^{\mathrm{h}} \pm 0.43$ & $39.25^{\mathrm{j}} \pm 0.52$ & $31.25^{\mathrm{i}} \pm 1.05$ \\
\hline April & $1^{\mathrm{st}}$ & 18.7 & 69.17 & $67.50^{\mathrm{f}} \pm 0.25$ & $50.75^{\mathrm{i}} \pm 0.66$ & $47.50^{\mathrm{h}} \pm 0.52$ \\
\hline April & $2^{\text {nd }}$ & 27.2 & 67.52 & $79.25^{\mathrm{e}} \pm 0.66$ & $63.00^{g} \pm 0.54$ & $61.50^{f} \pm 0.32$ \\
\hline April & $3^{\text {rd }}$ & 29.3 & 62.07 & $82.25^{\mathrm{de}} \pm 0.63$ & $55.25^{\mathrm{h}} \pm 0.31$ & $54.00^{\mathrm{g}} \pm 0.82$ \\
\hline April & $4^{\text {th }}$ & 24.35 & 58.18 & $95.25^{\mathrm{c}} \pm 0.63$ & $56.75^{\mathrm{h}} \pm 0.43$ & $66.75^{\mathrm{e}} \pm 0.63$ \\
\hline May & $1^{\mathrm{st}}$ & 29.5 & 64.31 & $115.50^{\mathrm{b}} \pm 0.85$ & $127.25^{\mathrm{c}} \pm 0.85$ & $99.50^{c} \pm 0.83$ \\
\hline May & $2^{\text {nd }}$ & 30.25 & 63.20 & $133.75^{\mathrm{a}} \pm 0.47$ & $156.00^{\mathrm{b}} \pm 0.20$ & $128.25^{\mathrm{b}} \pm 1.53$ \\
\hline May & $3^{\text {rd }}$ & 27.9 & 67.45 & $135.75^{\mathrm{a}} \pm 0.31$ & $160.75^{\mathrm{a}} \pm 0.43$ & $141.25^{\mathrm{a}} \pm 1.18$ \\
\hline May & $4^{\text {th }}$ & 30.65 & 64.78 & $83.50^{\mathrm{d}} \pm 0.92$ & $64.25^{\mathrm{g}} \pm 0.43$ & $143.75^{\mathrm{a}} \pm 0.24$ \\
\hline June & $1^{\mathrm{st}}$ & 30.4 & 70.32 & $93.25^{\mathrm{c}} \pm 0.47$ & $84.00^{\mathrm{f}} \pm 0.74$ & $52.25^{\mathrm{g}} \pm 0.55$ \\
\hline June & $2^{\text {nd }}$ & 30.95 & 68.19 & $69.75^{\mathrm{f}} \pm 1.23$ & $97.00^{\mathrm{d}} \pm 0.89$ & $69.00^{\mathrm{e}} \pm 0.61$ \\
\hline June & $3^{\text {rd }}$ & 27.25 & 72.09 & $59.75^{\mathrm{g}} \pm 0.43$ & $88.00^{\mathrm{e}} \pm 0.54$ & $74.50^{\mathrm{d}} \pm 1.23$ \\
\hline LSD 5\% & & & & 3.07 & 3.22 & 4.04 \\
\hline F test & & & & $* *$ & $* *$ & $* *$ \\
\hline \multicolumn{7}{|l|}{2014} \\
\hline March & $3^{\text {rd }}$ & 17.93 & 65.90 & $28.00^{\mathrm{h}} \pm 0.67$ & $23.75^{\mathrm{j}} \pm 0.57$ & $25.50^{\mathrm{i}} \pm 0.61$ \\
\hline March & $4^{\text {th }}$ & 19.66 & 70.18 & $24.50^{\mathrm{i}} \pm 0.59$ & $21.75^{\mathrm{k}} \pm 0.52$ & $23.75^{\mathrm{j}} \pm 0.57$ \\
\hline April & $1^{\mathrm{st}}$ & 18.46 & 65.86 & $32.00^{g} \pm 0.77$ & $28.25^{\mathrm{i}} \pm 0.68$ & $29.50^{\mathrm{h}} \pm 0.71$ \\
\hline April & $2^{\text {nd }}$ & 18.87 & 66.32 & $44.00^{\mathrm{e}} \pm 1.06$ & $33.50^{\mathrm{h}} \pm 0.81$ & $35.50^{\mathrm{g}} \pm 0.85$ \\
\hline April & $3^{\text {rd }}$ & 17.40 & 67.90 & $40.75^{\mathrm{f}} \pm 0.98$ & $38.00^{\mathrm{g}} \pm 0.91$ & $41.75^{\mathrm{f}} \pm 1.00$ \\
\hline April & $4^{\text {th }}$ & 19.54 & 65.81 & $62.00^{\mathrm{c}} \pm 1.49$ & $49.50^{\mathrm{d}} \pm 1.19$ & $58.50^{\mathrm{d}} \pm 1.41$ \\
\hline May & $1^{\mathrm{st}}$ & 21.13 & 67.03 & $78.00^{\mathrm{a}} \pm 1.88$ & $63.50^{\mathrm{a}} \pm 1.53$ & $76.75^{\mathrm{a}} \pm 1.85$ \\
\hline May & $2^{\text {nd }}$ & 23.64 & 70.16 & $69.50^{\mathrm{b}} \pm 1.67$ & $54.25^{\mathrm{b}} \pm 1.31$ & $62.75^{\mathrm{c}} \pm 1.51$ \\
\hline May & $3^{\text {rd }}$ & 22.21 & 66.48 & $71.25^{\mathrm{b}} \pm 1.71$ & $44.00^{\mathrm{e}} \pm 1.06$ & $72.00^{\mathrm{b}} \pm 1.73$ \\
\hline May & $4^{\text {th }}$ & 25.72 & 60.37 & $58.50^{\mathrm{d}} \pm 1.41$ & $52.00^{c} \pm 1.25$ & $55.25^{\mathrm{e}} \pm 1.33$ \\
\hline June & $1^{\mathrm{st}}$ & 26.10 & 53.93 & $62.25^{\mathrm{c}} \pm 1.50$ & $43.50^{\mathrm{e}} \pm 1.05$ & $54.75^{\mathrm{e}} \pm 1.32$ \\
\hline LSD 5\% & & & & 2.61 & 1.15 & 1.16 \\
\hline F test & & & & $* *$ & $* *$ & $* *$ \\
\hline \multicolumn{3}{|c|}{ cultivar mean over the two seasons } & & 69.35 & 63.35 & 63.84 \\
\hline Df & & & & & 66 & \\
\hline F value & & & & & $9.37 * *$ & \\
\hline $\mathrm{P}$ value & & & & & 0.031 & \\
\hline
\end{tabular}

All mean values are the arithmetic mean of the three replicates represented by the cultivars.

The values with the same letter are not significantly different at the probability level of $5 \%$, which carry different letters, differ significantly between them at the probability level of 5\%. 
Table 2.Population dynamics of Bemisia tabaci on Phaseolus vulgaris cultivars during the winter cropping seasons of 2013 and 2014 in Bihera Governorate

\begin{tabular}{|c|c|c|c|c|c|c|}
\hline \multirow{2}{*}{ Month } & \multirow{2}{*}{ Week } & \multirow{2}{*}{$\begin{array}{c}\text { Average } \\
\text { temperature } \\
\text { (C) }\end{array}$} & \multirow{2}{*}{$\begin{array}{l}\text { \% Relative } \\
\text { humidity }\end{array}$} & \multicolumn{3}{|c|}{$\begin{array}{l}\text { Population densities of } B \text {. tabaci on varieties of } \\
\text { common beans (Larva /week/30 leaves } \pm \mathrm{SE} \text { ) }\end{array}$} \\
\hline & & & & Copy & Polesta & Manga \\
\hline \multicolumn{7}{|l|}{2013} \\
\hline October & $2^{\text {nd }}$ & 23.93 & 66.43 & $24.25^{\mathrm{de}} \pm 0.42$ & $17.73^{\mathrm{h}} \pm 0.92$ & $14.79^{\mathrm{h}} \pm 1.22$ \\
\hline October & $3^{\text {rd }}$ & 21.18 & 63.67 & $27.25^{\mathrm{d}} \pm 0.74$ & $24.47^{\mathrm{e}} \pm 0.96$ & $19.57^{\mathrm{f}} \pm 1.70$ \\
\hline October & $4^{\text {th }}$ & 20.02 & 65.70 & $45.75^{\mathrm{bc}} \pm 1.02$ & $20.48^{\mathrm{g}} \pm 0.64$ & $23.08^{\mathrm{e}} \pm 2.01$ \\
\hline November & $1^{\mathrm{st}}$ & 18.50 & 64.73 & $43.00^{c} \pm 0.61$ & $28.72^{\mathrm{d}} \pm 0.95$ & $33.37^{\mathrm{c}} \pm 2.91$ \\
\hline November & $2^{\text {nd }}$ & 17.69 & 62.48 & $48.00^{\mathrm{b}} \pm 1.63$ & $35.46^{\mathrm{a}} \pm 0.86$ & $42.65^{\mathrm{b}} \pm 3.72$ \\
\hline November & $3^{\mathrm{rd}}$ & 16.50 & 63.19 & $52.75^{\mathrm{a}} \pm 0.54$ & $34.46^{\mathrm{b}} \pm 0.75$ & $48.92^{\mathrm{a}} \pm 4.26$ \\
\hline November & $4^{\text {th }}$ & 17.11 & 63.95 & $27.75^{\mathrm{d}} \pm 0.61$ & $29.97^{\mathrm{c}} \pm 0.95$ & $31.86^{\mathrm{c}} \pm 2.78$ \\
\hline December & $1^{\mathrm{st}}$ & 17.16 & 69.90 & $22.75^{\mathrm{e}} \pm 0.35$ & $21.48^{\mathrm{f}} \pm 0.72$ & $29.10^{\mathrm{d}} \pm 2.54$ \\
\hline December & $2^{\text {nd }}$ & 15.49 & 70.17 & $21.00^{\mathrm{e}} \pm 0.35$ & $13.24^{\mathrm{j}} \pm 0.77$ & $14.55^{\mathrm{h}} \pm 1.27$ \\
\hline December & $3^{\mathrm{rd}}$ & 17.88 & 68.53 & $16.25^{\mathrm{f}} \pm 0.41$ & $14.73^{\mathrm{i}} \pm 0.74$ & $16.81^{\mathrm{g}} \pm 1.46$ \\
\hline December & $4^{\text {th }}$ & 16.92 & 66.71 & $15.00^{\mathrm{f}} \pm 0.54$ & $11.74^{\mathrm{k}} \pm 0.80$ & $12.79^{\mathrm{i}} \pm 1.11$ \\
\hline LSD 5\% & & & & 4.34 & 1.09 & 2.04 \\
\hline F test & & & & $* *$ & $* *$ & $* *$ \\
\hline \multicolumn{7}{|l|}{2014} \\
\hline October & $2^{\text {nd }}$ & 22.74 & 64.89 & $22.00^{\mathrm{h}} \pm 0.61$ & $13.25^{\mathrm{j}} \pm 0.37$ & $16.00^{\mathrm{h}} \pm 0.44$ \\
\hline October & $3^{\text {rd }}$ & 23.46 & 65.03 & $24.00^{\mathrm{g}} \pm 0.67$ & $12.25^{\mathrm{k}} \pm 0.34$ & $13.00^{\mathrm{i}} \pm 0.36$ \\
\hline October & $4^{\text {th }}$ & 19.82 & 63.46 & $35.75^{\mathrm{e}} \pm 0.99$ & $16.75^{\mathrm{g}} \pm 0.47$ & $19.00^{f} \pm 0.53$ \\
\hline November & $1^{\mathrm{st}}$ & 18.39 & 66.27 & $37.75^{\mathrm{d}} \pm 1.05$ & $15.50^{\mathrm{i}} \pm 0.43$ & $18.25^{\mathrm{g}} \pm 0.51$ \\
\hline November & $2^{\text {nd }}$ & 18.07 & 60.67 & $43.50^{\mathrm{c}} \pm 1.21$ & $28.00^{\mathrm{a}} \pm 0.78$ & $33.75^{\mathrm{a}} \pm 0.94$ \\
\hline November & $3^{\text {rd }}$ & 17.44 & 62.34 & $48.75^{\mathrm{b}} \pm 1.36$ & $20.25^{\mathrm{e}} \pm 0.56$ & $29.25^{\mathrm{b}} \pm 0.81$ \\
\hline November & $4^{\text {th }}$ & 16.32 & 60.72 & $52.50^{\mathrm{a}} \pm 1.46$ & $16.00^{\mathrm{h}} \pm 0.44$ & $22.25^{\mathrm{e}} \pm 0.62$ \\
\hline December & $1^{\text {st }}$ & 15.18 & 69.28 & $38.25^{\mathrm{d}} \pm 1.06$ & $23.25^{\mathrm{c}} \pm 0.65$ & $29.50^{\mathrm{b}} \pm 0.82$ \\
\hline December & $2^{\text {nd }}$ & 15.21 & 70.66 & $32.25^{\mathrm{f}} \pm 0.90$ & $24.50^{\mathrm{b}} \pm 0.68$ & $28.50^{\mathrm{c}} \pm 0.79$ \\
\hline December & $3^{\text {rd }}$ & 15.54 & 69.14 & $22.75^{\mathrm{h}} \pm 0.63$ & $18.75^{\mathrm{f}} \pm 0.52$ & $22.75^{\mathrm{e}} \pm 0.63$ \\
\hline December & $4^{\text {th }}$ & 16.01 & 68.30 & $20.75^{\mathrm{i}} \pm 0.58$ & $21.75^{\mathrm{d}} \pm 0.60$ & $24.75^{\mathrm{d}} \pm 0.69$ \\
\hline LSD 5\% & & & & 0.94 & 0.42 & 0.55 \\
\hline F test & & & & $* *$ & $* *$ & $* *$ \\
\hline cultivar mea & ver the $t$ & seasons & & 32.25 & 21.03 & 24.75 \\
\hline Df & & & & & 60 & \\
\hline F value & & & & & $8.63 * *$ & \\
\hline$P$ value & & & & & 0.047 & \\
\hline
\end{tabular}

All mean values are the arithmetic mean of the three replicates represented by the cultivars.

The values with the same letter are not significantly different at the probability level of $5 \%$, which carry different letters, differ significantly between them at the probability level of $5 \%$. 
Table 3. Varietal Screening of common bean Phaseolus vulgaris cultivars against Bemisia tabaci during summer and winter growing seasons of 2013 and 2014 in EL-Beheira Governorate

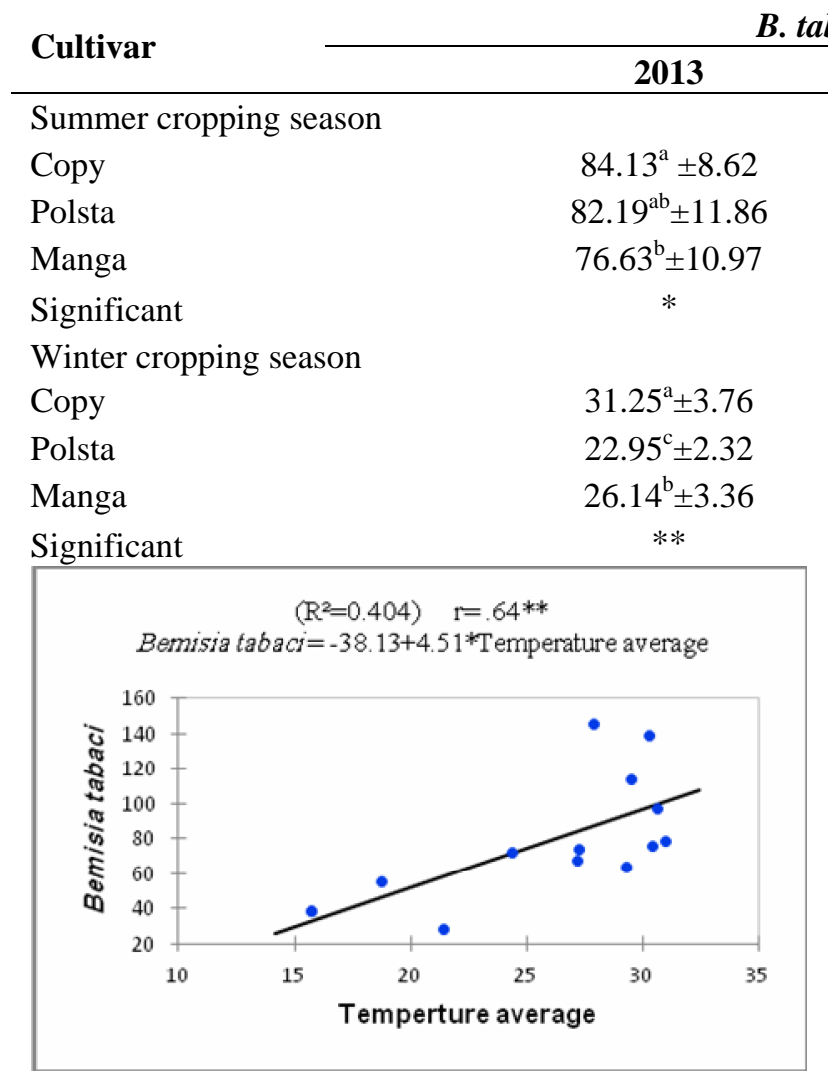

Figure 1. Effect of weakly mean temperature on the population density of Bemisia tabaci infesting Phaseolus vulgaris during 2013 summer growing season

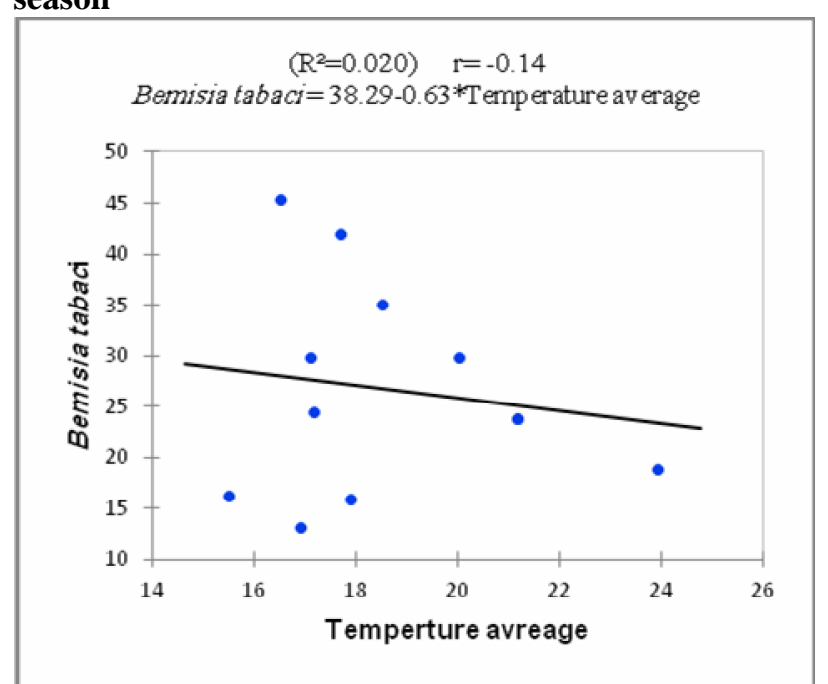

Figure 3. Effect of weakly mean temperature on the population density of Bemisia tabaci infesting Phaseolus vulgaris during 2013 winter growing

2014

$51.89^{\mathrm{a}} \pm 5.21$

$41.09^{\mathrm{b}} \pm 3.71$

$48.73^{\mathrm{a}} \pm 5.15$

$34.39^{\mathrm{a}} \pm 3.08$

$10.11^{\mathrm{c}} \pm 1.37$

$23.36^{\mathrm{b}} \pm 1.79$

$* *$

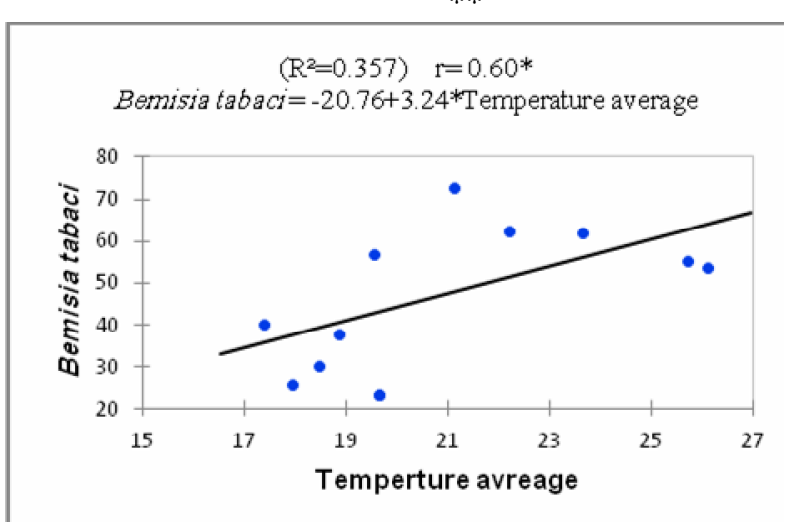

Figure 2. Effect of weakly mean temperature on the population density of Bemisia tabaci infesting Phaseolus vulgaris during 2014 summer growing season

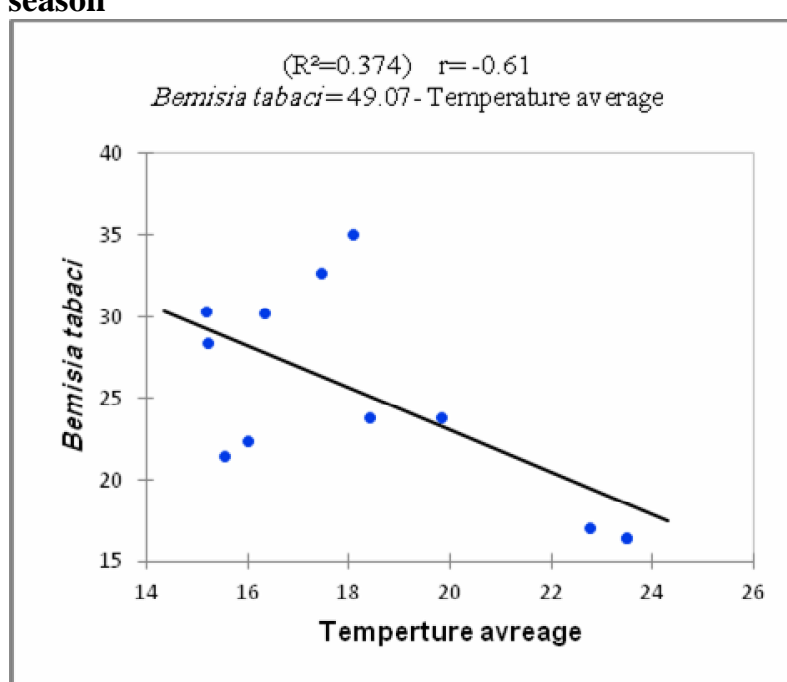

Figure 4. Effect of weakly mean temperature on the population density of Bemisia tabaci infesting Phaseolus vulgaris during 2014 winter growing 
season

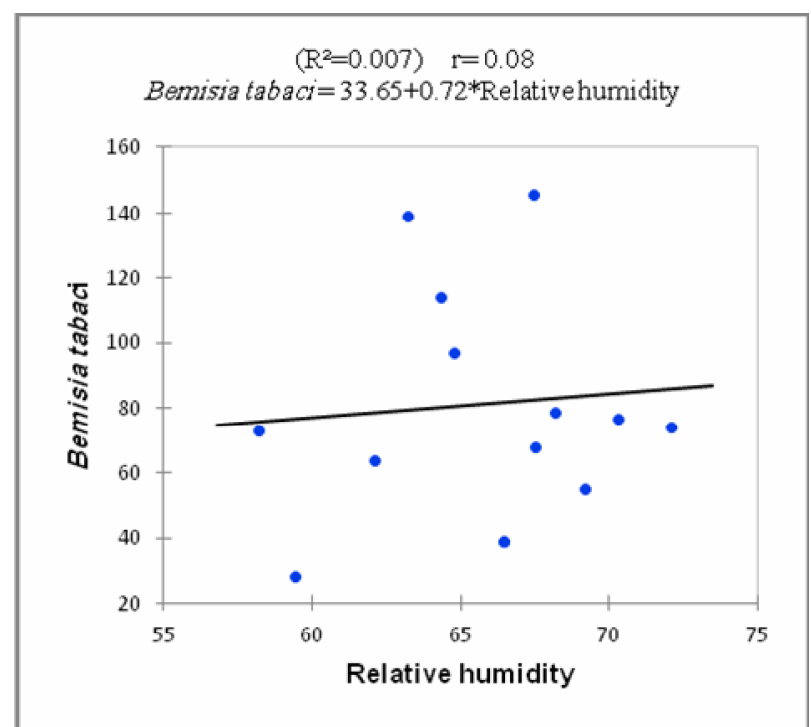

Figure 5. Effect of weakly mean relative humidity on the population density of Bemisia tabaci infesting Phaseolus vulgaris during 2013 summer growing season

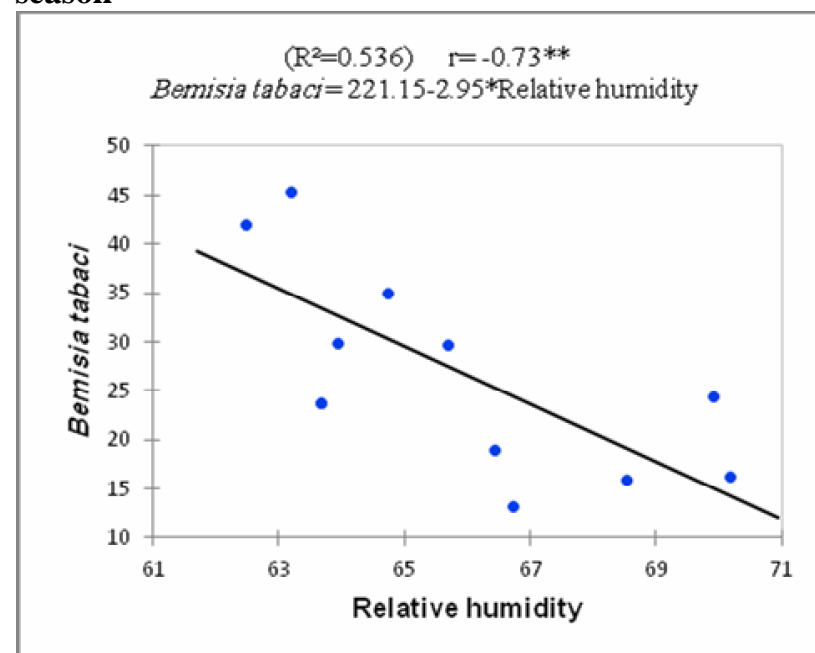

Figure 7. Effect of weakly mean relative humidity on the population density of Bemisia tabaci infesting Phaseolus vulgaris during 2013 winter growing season

\section{DISCUSSION}

The present study indicated that the populations of B. tabaci infesting the three common bean cultivars during crop seasons of 2013 and 2014 were initially detected in early March. Densities of this pest typically increased as the growing season progressed and reached a peak in the month of May and started to decrease from $1^{\text {st }}$ June until the end of the June in Etay EL-Baroud distract EL-Behiera governorate condition. Gupta and season

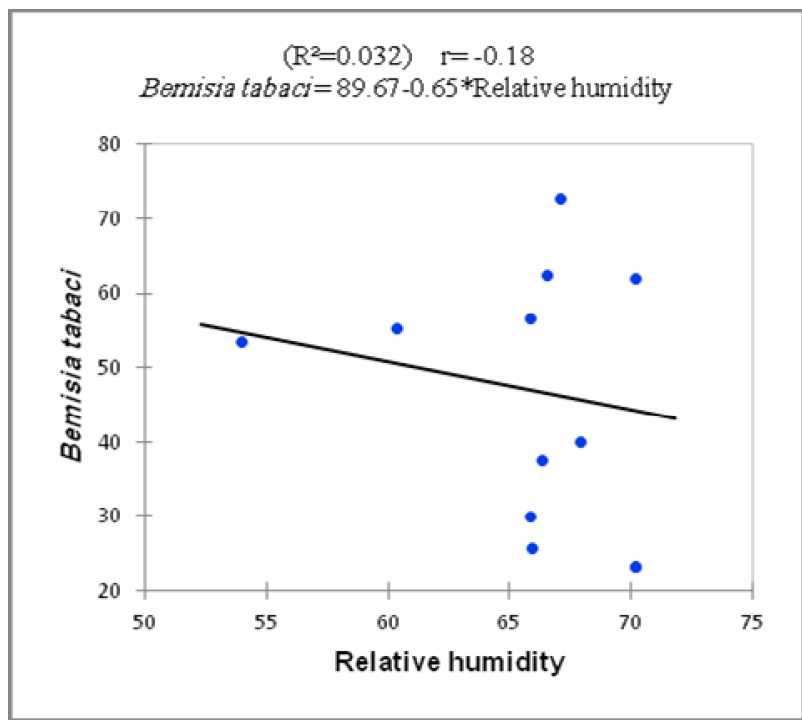

Figure 6. Effect of weakly mean relative humidity on the population density of Bemisia tabaci infesting Phaseolus vulgaris during 2014 summer growing season

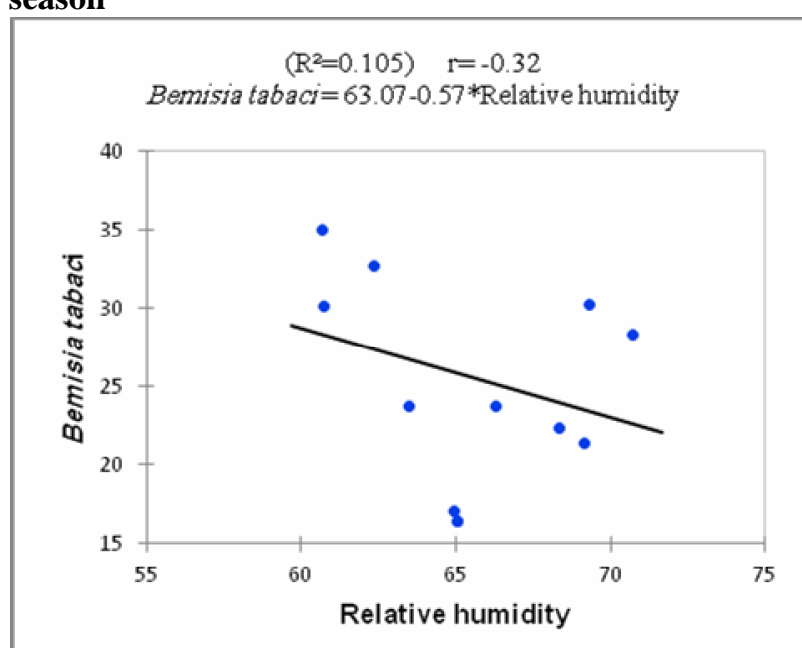

Figure 8. Effect of weakly mean relative humidity on the population density of Bemisia tabaci infesting Phaseolus vulgaris during 2014 winter growing season

Singh (1993) found in India that the highest number of B. tabaci was recorded during April for some leguminous crops especially common bean varieties. The whitefly population decreased when the temperature was less than $25{ }^{\circ} \mathrm{C}$ or more than $30{ }^{\circ} \mathrm{C}$. During the winter cropping season, the population density of whitefly increased during November and that almost happened when the average temperature ranged between 16 and $18{ }^{\circ} \mathrm{C}$ and the relative humidity between $60 \%$ and $65 \%$. Gamila Sh. Selem et al. (2016) reported 
two peaks of $B$. tabaci on kidney beans, the first occurred in the first week of May and the second peak occurred in the first week of June at the 24.9 ?C., 25.7 ?C. with $57.0 \%$ and $57.1 \%$ R.H.

Densities of $B$. tabaci typically increased as the growing season progressed and reached a peak in November and started to decrease from December until the end of the seasons. In 2013 and 2014 cropping seasons, the population densities gradually increased from the $2^{\text {nd }}$ week of October until the $4^{\text {th }}$ week of October. Thereafter, the population density reached a peak from the $1^{\text {st }}$ week of November, and then decreased gradually from the $4^{\text {th }}$ week of November until the $4^{\text {th }}$ week of December in 2013 and 2014. This result were agree with Hegab et al. (2005) who indicated that $B$. tabaci population increased from August and peaked in December. Also, Amaar et al. (2014) reported that the activity period of $B$. tabaci nymphs was during October and November. On the other hand, the whitefly population was decreased when the temperature was less than $15^{\circ} \mathrm{C}$.

The number of white flies infesting the three cultivars was statistically significant during 2013 and 2014 summer and winter cropping seasons. In 2013 summer cropping season, the cultivars Copy and Polesta were the most susceptible varieties while, the cultivar Manga was less susceptible one. In 2013 winter cropping season, the cultivars Copy and Manga were more susceptible to whitefly infestation than Polesta cultivar. The same trend was observed during the winter cropping season of 2014. The most susceptible varieties were Copy and Manga respectively. Whereas Polesta variety was the least susceptible. Therefore, Copy and Manga varieties can recommended for farmers to reduce infestation with $B$. tabaci and to improve common bean production. El-Saidy et al. (2012) reported that common bean cultivar Hama was more susceptible than Polista cultivar. The authors found significant differences between the two kidney bean cultivars for B. tabaci the susceptibility of the two cultivars to these insect infestations was also varied during the two studied seasons. The variation in susceptibility among common bean varieties may be due to certain inherited characters. Plants have many morphology and physical characteristics that keep insects away such as plant thorns, hairs, and tough roots and stems, color, hairiness, hardness, and cuticle waxes (Finch and Collier, 2000). In addition, a wide range of repellent or toxic chemical substances are known to render cultivars less suitable or unsuitable to a wide array of insect-pests (Dhaliwal and Arora, 2003).

The present study showed a significant difference between the two summers season of 2013 and 2014 in population density of $B$. tabaci where the population density in 2013 was exceeded the population in 2014 and with the observation of all condition over the two seasons. We can find highly similarity in most conditions such the time of planting and harvest, date of insect collected and relative humidity only temperature average was differed over the two seasons, where the first season was more hot with temperature average $\left(26.43^{\circ} \mathrm{C}\right)$ over the whole season than the second season $\left(20.97^{\circ} \mathrm{C}\right)$, this differ in temperature average may be the major reason of the increase of the population density in 2013 more than 2014 summer season. B. tabaci population density was positively affected by temperature in 2013 and 2014 summer growing seasons where the correlation coefficient were 0.64 and 0.6 respectively. Also, our result clearly indicate that $B$. tabaci start infestation when the temperature average was above $15^{\circ} \mathrm{C}$, The population density reached a peak when the temperature average ranged between 20 and $30{ }^{\circ} \mathrm{C}$. Therefore, the population density decreased when the temperature exceeded $30{ }^{\circ} \mathrm{C}$. In contrast, in 2013 and 2014 winter cropping season the relationship between $B$. tabaci population and temperature was insignificant and/or significant negative with a correlation coefficient of -0.14 and -0.61 , respectively. The present study revealed that the relative humidity showed non-significant positive association with $B$, tabaci abundance in 2013 summer growing season with correlation coefficient of 0.08 . On the other hand, $B$. tabaci density showed non-significant negative association with relative humidity in 2014 summer season and 2013 winter seasons and significant negative association in 2014 winter season with correlation coefficients of $0.18,0.73$ and 0.32 , respectively.. The present results get support from the observations of Nayak et al. (2004) who reported that the minimum temperature was positively correlated with $B$. tabaci.

\section{REFERENCES}

Amaar, Mona I., S. A. EL-Refai, Rania S.A. Rashwan and M. F. A. H. Hegab. 2014. Population dynamics and control of certain pests Infesting green bean (phaseolus vulgaris) at Qalubiya governorate, egypt. Egypt. J. Agric. Res., 92 (3): 113-124.

Basu, A.N. 1995. Bemisia tabaci (Gennadius): Crop Pest and Principal Whitefly Vector of Plant Viruses. Oxford and IBH Publishing Co. Pvt. Ltd. New Delhi, Bombay, Calcutta, India. Pp. 1-183.

Dhaliwal, G. S. and R. Arora, 2003. Integrated Pest Management: Concepts and Approaches, Kalyani Publishers, New Delhi. 427p. Dhankhar, 1997

El-Saidy E.M.A., Aziza M. M. Abou-Zaid and Amna, M.H. Maklad . 2012. Evaluation of the Susceptibility of two Kidney Bean Cultivars to the Infestation of the TwoSpotted Spider Mite and Some Sap-Suking Insects and 
Their Relations with Some Abiotic Factors. J. of App. Sci. Res., 8(11): 5543-5549.

FAO STAT .2014. Common bean production. Food and Agriculture Organization of the United Nation 2014.

Filella, I. and J. Penuelas.1994. The Red Edge Position and Shape as Indicators of Plant Chlorophyll Content, Biomass and Hydric Status. Int. J. of Remote Sensing, 5, $1459-1470$.

Finch, S., and R.H. Collier.2000. Host plant selection by insects -a theory based on ,appropriate/inappropriate landings" by pest insects of cruciferous plants. Ento. Exper. et App. 96: 91- 102.

Gameel, O. I. 1973. Field evaluation of insecticides for jassid, Empoasca lybica De Berg and whitefly, Bemisia tabaci (Genn.) control on cotton. Bull. Entomo. Soc. Egypt, Econo. Ser. 7: 113-122.

Gamila Sh. Selem, Heba A. Ismail and A. A. Abd-Elsamad .2016. Population fluctuations of the main pests infesting kidney beans and its relation with some weather factors Ann. of Agric. Sci., Moshtohor. 54(4): 969-976.
Gupta, P.K. and J. Singh.1993. Population studies on insect pests of Green gram (Vigna radiata (L.) Wilczek). Indian J. of Entomology. 55(1): 45-51.

Hassan, A.M., O. A. Zaghloul, Nagda, A.El-sayed, Nabil A. Hassan and , Rania, S.Ammar.2016. Dynamical Seasonal Fluctuations of the Prevailing Insect-Pests on Faba Bean and Garden Pea Plantations at Alexandria Governorate, Egypt. Alex. Sci. Exch. J. 37 (4) : 669-678.

Hegab, A.M., M.M. El-Zohairy, A.A. Attia, and A.A.A. Youssef.2005. Survey and seasonal abundance of leafhoppers infesting some leguminous crops. Zagazig J. Agric. Res. 32 (5): 1649-1662.

Katungi, E., A. Farrow, J. Chianu, L. Sperling and S. Beebe.2009. Common Bean in Eastern and Southern Africa: A Situation and Outlook Analysis. Int. Cen. for Trop. Agri. 61.

Nayak, S.K., R. Ujagir, and R.C. Chhibber.2004. Effect of abiotic factors on the insect population build up on Black gram, Vigna mungo L. crop. Shashpa 11(1): 31-36.

Oliveira, M. R. V., T. J. Henneberry, and P. Anderson. 2001. Host, current status, and collaborative research projects for Bemisia tabaci. Crop Protection (20): 709-723. 


\section{الملخص العربي}

تذبذب الكثافة العددية لعشيرة الأبابة البيضاء على نباتات الفاصوليا و علاقتها بالصنف المنزرع و

\section{درجات الحرارة و الرطوبة الجوية}

أمال ابر اهيم سيف، السعيد احمد نعيم ،حوريةعلى عبد الوهاب و كمال محمد الجندى

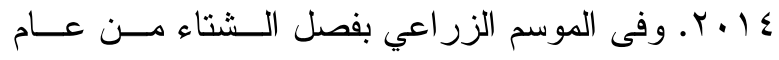

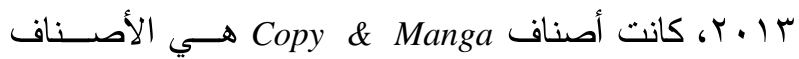

الأكثز إصابة بآفة الذبابة البيضاء من صنف Polesta. ونتم

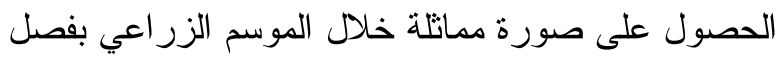

الشتاء من عام ع ا ـ r. حيث كانت الأصناف الأكثر إصابة

هي Copy و Manga على التو الي، فيما كان صنف Polesta هو الأقل إصابة. لقد تأثرت أعداد آفة الذبابة البيضاء بشكل فئل إيجابي بفعل درجة الحرارة فى مو اسم النمو بفصل الصيف

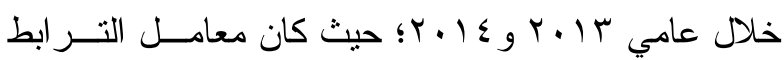

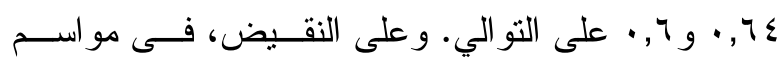

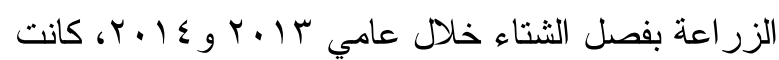
العلاقة بين آفة الذبابة البيضاء ودرجة الحر ارة علاقة سلبية

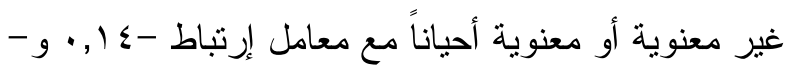

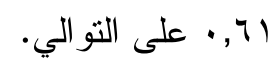

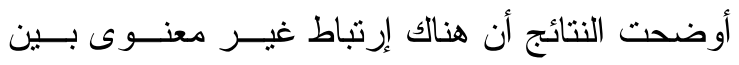

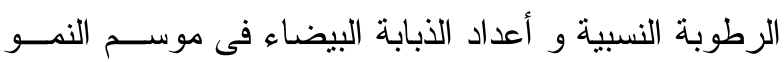

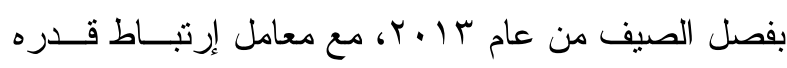

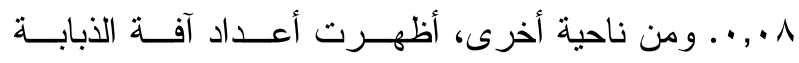
البيضاء إرتباط سلبي غير معنوى الرطوبة النسبة فى موسم

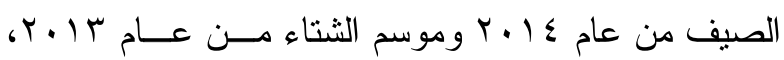

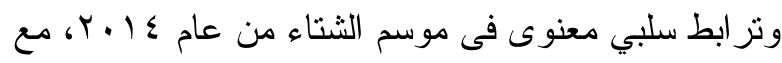

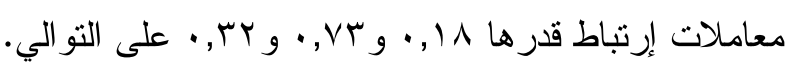

كان الهذف من هذه الدر اسة هو تحديد العلاقة الـسببية

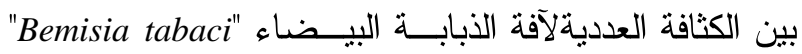
و أصناف الفاصوليا (Copy, Polesta \& Manga) من حيــث درجة الحرارة و الرطوبة، خلال فصلي الــصيف و الـشتثاء

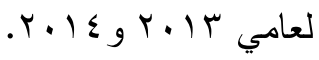

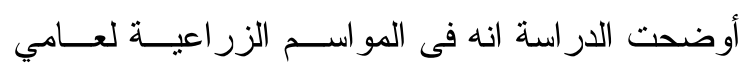

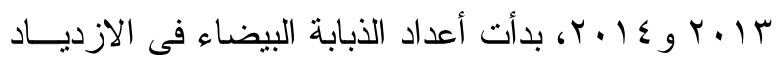

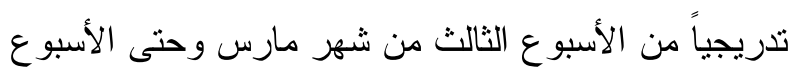

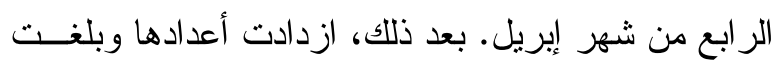

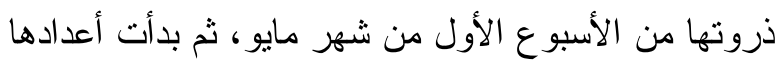

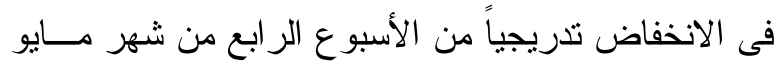

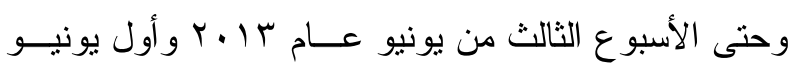
.$r \cdot 1 \varepsilon$

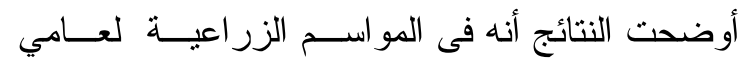

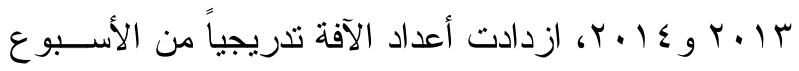

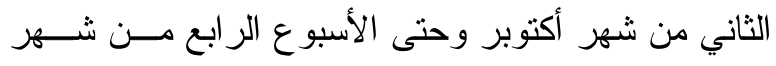

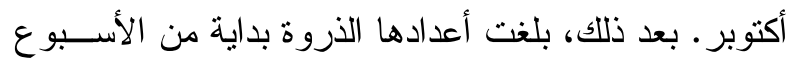

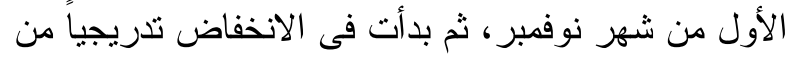

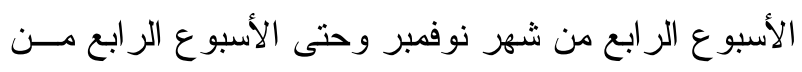

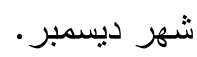

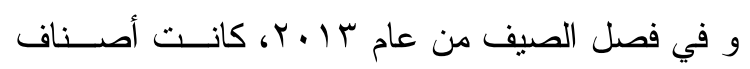
Copy \& Polesta

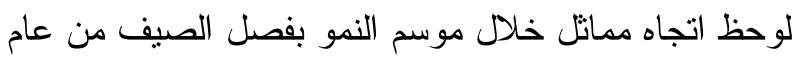

